\title{
Microevolution on Anthropogenically Changed Areas on the Example of Biscutella laevigata Plants from Calamine Waste Heap in Poland
}

\section{Małgorzata Wierzbicka ${ }^{1 *}$, Maria Pielichowska², Olga Bemowska-Kałabun ${ }^{1}$ and Paweł Wąsowicz ${ }^{3}$}

${ }^{1}$ Faculty of Biology, University of Warsaw, I Miecznikowa 1, 02-09 Warsaw, Poland

${ }^{2}$ The Maria Grzegorzewska Academy of Special Education, Szczęśliwicka 40, 02-353 Warsaw, Poland

3 Icelandic Institute of Natural History, Borgir við Norðurslóđ, PO Box 180, IS-602 Akureyri, Iceland

\begin{abstract}
In the era of increasing environmental pollution, microevolutionary processes occurring in plants inhabiting anthropogenic areas play a special role. With time, these processes may lead to formation of new plant species. A good example of occurrence of microevolutionary processes on anthropogenically altered areas is the metallophyte Biscutella laevigata $\mathrm{L}$. The studies have shown the existence of significant morphological, anatomical and physiological differences between two groups of the $B$. laevigata populations occurring in Poland - the population of calamine waste heaps in Bolesław near Olkusz (Silesian Upland) and the population inhabiting the Tatra Mountains (Western Carpathians). The demonstrated differences are the adaptation (hereditary characteristics) of the plants to the unfavorable conditions of the calamine waste heap, i. a. high concentration of heavy metals in the soil. The research has also shown theexistence of significant differences between these two groups of populations - both at the genetic and morphological levels (a clonal form of vegetative propagation, removal of heavy metals by the oldest and drying leaves, a zinc tolerant species, trichomes accumulating metals, metal detoxification at the cellular level). The demonstrated differences between the zinc-lead (calamine) waste heap population and the Tatra Mountains population indicate the existence of the new subspecies of Biscutella laevigata subsp. woycickii on the heaps in Boleslaw, in Poland.
\end{abstract}

Keywords: Review; Biscutella laevigata; Metallophyte; Heavy metals; Tolerance; Microevolution

\section{Introduction}

The study of microevolutionary processes occurring in the anthropogenically altered environment is now one of the fundamental issues of ecotoxicology. The development of increased plant tolerance for heavy metals is a model process, used in studies on evolution leading to adaptation of organisms to extremely unfavorable habitats. We understand the microevolution as the processes of genetic differentiation within the population of a given species caused by mutations, genetic drift and natural selection determined by local environmental factors. New genetic adaptations are hereditary and increase the probability of survival, as well as the reproduction of plants in a particular environment [1-4].

Heavy metals such as lead, cadmium, mercury or thallium are among the most dangerous pollutants in the environment. Unlike some organic harmful substances, heavy metals naturally occur in rock-forming minerals and ores. Heavy metal pollution means the occurrence of abnormally high concentrations of metals in relation to their geochemical background. Mining, metallurgical industry, electronics, transportation, additives for fuel and lubricating oil, or agricultural materials are just some of many sources of heavy metals in the environment. The toxic effects of excessive concentrations of heavy metal ions in plants are i. a.: disorders in the functioning of cell membranes, disturbance of photosynthesis, cellular respiration disorder, transpiration disorder, protein and enzyme inhibition, interfering with electron transport or inhibition of plant growth [5-7].

As a result of the action of the harmful agent, the selection of individuals occurs followed by the survival of those with effective defense capabilities (e.g., individuals with a high ability to detoxify metals). The result of occurrence of these processes is the formation of plants with higher tolerance to a given factor, so called induced tolerance [1,3-4].

In the areas contaminated with heavy metals, such as waste heaps, many metallophyte species occur, for example: Biscutella laevigata,
Dianthus carthusianorum, Armeria maritima, Silene vulgaris, Viola guestphalica, V. calaminaria, V. reichenbachiana, V. riviniana or Arabidopsis arenosa. These species have a number of adaptations that allow them to survive the unfavorable environmental conditions. We can mention here: ability to detoxify metals in protoplast or cell wall, as well as development of " $r$ " reproductive strategies in some species of plants from the metal-bearing areas (formation of plants with a shortened life cycle and rapid entry into the generative phase). Numerous studies show that there are significant differences between populations in heavily contaminated areas and uncontaminated areas, which suggests the emergence of new ecotypes and even new subspecies [1,4,8-18].

This article is a summary of knowledge about one of the most interesting metallophytes, Biscutella laevigata.

Biscutella laevigata $\mathrm{L}$. is a mountain perennial species and a member of Brassicaceae family. This species belongs to the Biscutella genus. $B$. laevigata reaches from 10 to $40 \mathrm{~cm}$ in height. The stem of $B$. laevigata, usually branched at the top, is covered with downwardly directed trichomes. Basal leaves are usually $3-12 \mathrm{~cm}$ long, and have lanceolate shape. The edge of basal leaves can be roughly serrated or rounded. Basal leaves are usually covered with trichomes on both sides. Stem leaves are few (usually 3 to 6), sitting (without a leaf stalk), and leaf base often slightly surrounds the stem. Stem leaves are lanceolate. Their hair may resemble those found on basal leaves. Sepals are 2.5-3 $\mathrm{mm}$ long.

*Corresponding author: Małgorzata Wierzbicka, Faculty of Biology, University of Warsaw, I. Miecznikowa 1, 02-09 Warsaw, Poland, Tel: +48225542003. E-mail: wierzbicka@biol.uw.edu.pl

Received June 05, 2017; Accepted June 12, 2017; Published June 19, 2017

Citation: Wierzbicka M, Pielichowska M, Bemowska-Kałabun O, Wąsowicz P (2017) Microevolution on Anthropogenically Changed Areas on the Example of Biscutella laevigata Plants from Calamine Waste Heap in Poland. J Environ Anal Toxicol 7: 471. doi: 10.4172/2161-0525.1000479

Copyright: $\odot 2017$ Wierzbicka M, et al. This is an open-access article distributed under the terms of the Creative Commons Attribution License, which permits unrestricted use, distribution, and reproduction in any medium, provided the original author and source are credited. 
Citation: Wierzbicka M, PielichowskaM, Bemowska-Kałabun O, Wąsowicz P (2017) Microevolution on Anthropogenically Changed Areas on the Example of Biscutella laevigata Plants from Calamine Waste Heap in Poland. J Environ Anal Toxicol 7: 471. doi: 10.4172/2161-0525.1000479

Page 2 of 10

Petals are light yellow, and are 2-4 mm long. Flowers form the raceme inflorescence. Flowers are set on a bare pedicel of 6 to $12 \mathrm{~mm}$ in length. The fruit of B. laevigata is a silique. Seeds are strongly flattened, broad ovate and 3-4 mm long. Ripe fruit and stems, at the end of the growing season, turns into reddish-purple color [19-22].

B. laevigata is a perennial plant, strictly allogamous, with a developed system of sporophytic self-incompatibility [23]. Field studies indicate that B. laevigata flowers are mainly pollinated by the Diptera order [24]. In the Raunkiær plant life-forms system, the species is classified as a hemicryptophyte, a perennial plant regenerating from buds located at the ground level [25].

B. laevigata occurs mainly in locations with very strong insolation and is broadly tolerant to various climatic conditions: from mildly temperate areas (such as subalpine and upper alpine areas) to areas with moderately warm climates (prevailing on lowland areas). It prefers the mineral-humous soil, fresh, poor in minerals (oligotrophic) and alkaline $(\mathrm{pH}>7)$.

The geographical range of $B$. laevigata includes the central part of Europe, particularly in mountain areas and their surroundings. It is also found in the lowlands north of the Alps and the Carpathians Mountains (Figure 1). The location of this mountain species in Poland is rather intriguing. These are only three geographically isolated posts in the southern part of the country, distant from each other by 100 kilometers. One population is located in the area of the Western Tatra Mountains, typical for the mountain species. The second one, however, is located in the lowlands highly contaminated with heavy metals. These are lead-zinc waste heaps in Boleslaw near Olkusz. The third population is located in the lowland in Zagórzyce near Pińczów and is related to the population of Boleslaw [18,21,26-31]. B. laevigata occurs in Poland mainly in mountain rock grassland communities on a substrate containing significant amounts of calcium carbonate [32].

B. laevigata is a very variable plant species. A large number of subspecies throughout Europe was described. Until recently it seemed that only two of these subspecies could be found in Poland: subsp. kerneri Mach.-Laur. and subsp. gracilis Mach.-Laur. The morphological differences between these subspecies are not sharp and unambiguous, which makes their determination difficult and extremely doubtful [4]. Research on plants occurring in the Olkusz ore-bearing region

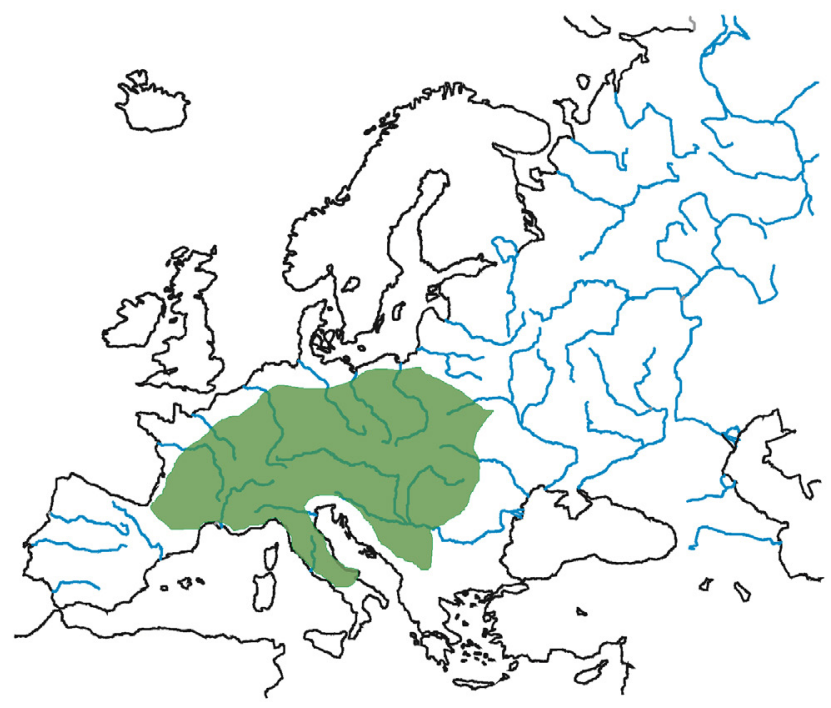

Figure 1: The geographical distribution of $B$. laevigata $[4,70]$ appears to indicate the presence of a new subspecies, showing strong genetic divergence $B$. laevigata subsp. woycickii subsp nov [4,17]. The basic number of the $B$. laevigata chromosomes examined in the Polish populations is $2 \mathrm{n}=18$ [33].

\section{Biscutella laevigata on Zinc-Lead (Calamine) Waste Heap in Bolesław near Olkusz}

For many years it has been a mystery, which processes led to such abundant presence of the B. laevigata mountain plant in lowland and often in metallic soils. The first mention of $B$. laevigata occurring in the vicinity of Olkusz dates back to 1877 [34]. This area is very rich in metalbearing soils - especially zinc-lead waste heaps (calamine). Particularly interesting, in terms of floristic studies, is the over 100-year old heap in Boleslaw near Olkusz, where no recultivation works were carried out, and all the vegetation present theregrew as a result of natural succession. This waste heap is partly protected (the ecological use) due to the presence of $B$. laevigata. This species can be found in a larger area - it is covered with hollows and warps (calamine waste heaps) from former mining outcrops as well as freshly built waste heaps $[21,26,29,31,35]$.

This area is extremely rich in heavy metals. In the upper layers of the soil $(0-5 \mathrm{~cm})$ there is $5.2 \%$ zinc, $0.31 \%$ lead, $5.5 \%$ iron, $0.018 \%$ cadmium - with a fairly high $\mathrm{pH}$ 7.3-8.2. Under these conditions, the availability of heavy metals to plants is relatively low and is equal to several percent of the overall total metal concentration [36]

On the old waste heap in Boleslaw, where B. laevigata occurs, two types of its locations can be distinguished due to humidity conditions:

- xerothermic areas where B. laevigata is a pioneer plant, on a calamine subsoil, without co-occurrence of other plants; these are initial areas;

- more humid areas where B. laevigata occurs in the company of other plants; these are places with a high ratio of vegetation cover [28].

Depending on the location, B. laevigata plants varied in size (the smallest on the xerothermic site), but on average the leaves of these plants were $4( \pm 1.34) \mathrm{cm}$ long and $0.8( \pm 0.3) \mathrm{cm}$ wide. They were almost completely (75-100\%) covered with trichomes, and the leaves color was light green to green (Figure 2) [28]. Flowering and fruiting occurs between April and June, and the presence of a certain number of flowering individuals was also observed in autumn (September October). As a rule, seeds of these plants are small, with an average weight of $1.8( \pm 0.1) \mathrm{mg}$. The germination ability of the seeds was about $70 \%$ and remained at this level for another three years [28].

The B. laevigata plants growing on the waste heap (Figure 2), had a significantly elevated amount of heavy metals in the tissues. Two factors influenced the amount of metals accumulated by plants: the growth period (sampling in June or November) and the site of growth (calamine subsoil, with or without accompanying plants). The highest concentrations of metals were observed in individuals growing on initial sites, on calamine subsoil and at the end of the growing season (November). For example, during the vegetative period of B. laevigata (June - November), lead concentrations in the roots increased on average three times (from $80 \mathrm{mg} / \mathrm{kg}$ to $240 \mathrm{mg} / \mathrm{kg}$ dry mass), whereas in leaves - four times (from $28 \mathrm{mg} / \mathrm{kg}$ to $230 \mathrm{mg} / \mathrm{kg}$ dry mass). Similar dependence was found for zinc (from $800 \mathrm{mg} / \mathrm{kg}$ to $2618 \mathrm{mg} / \mathrm{kg}$ dry mass) and cadmium ( $5 \mathrm{mg} / \mathrm{kg}$ to $35 \mathrm{mg} / \mathrm{kg}$ dry mass). The amount of heavy metals in the B. laevigata plant tissues was dependent on the period of vegetation (most in autumn) and the plant growth site (most on calamine subsoil). However, in any case, organs of the $B$. 
Citation: Wierzbicka M, PielichowskaM, Bemowska-Kałabun O, Wasowicz P (2017) Microevolution on Anthropogenically Changed Areas on the Example of Biscutella laevigata Plants from Calamine Waste Heap in Poland. J Environ Anal Toxicol 7: 471. doi: 10.4172/2161-0525.1000479

laevigata plants, which were growing on the zinc-lead waste heap, had significantly higher levels of heavy metals, compared to the average amount found in plants: lead - about 15 times, zinc - about 28 times, cadmium - about 83 times [37].

\section{Biscutella laevigata in Tatra Mountains}

B. laevigata occurs in the mountains, on limestone substrates in the Western Tatra Mountains (Figure 3). It grows on the rendzina soil, formed on the substrate of carbonate rocks $[36,38]$. The soil research in the Tatra National Park (1996-1998) has shown that the rendzina soil belongs to the soils with a relatively high content of heavy metals: zinc (81-745 mg/kg dry mass), lead (38-411 mg/kg dry mass), and cadmium (0.40-17 $\mathrm{mg} / \mathrm{kg}$ dry mass). However, those values are relatively low in comparison to those obtained for subsoils from calamine waste heaps. The contamination with heavy metals of top layers of the Tatra soil was related to the composition of the bedrock and was dependent on industrial dust pollution. The contamination increased with the height of $\mathrm{m}$ a.s.l. and it was the greatest for the slopes of the north-west exposure $[4,39]$.

B. laevigata as a mountain species can be encountered even above the heights $2128 \mathrm{~m}$ a.s.l., where it grows on limestone rocks and talus deposits. Usually it occupies dry, warm and sunny habitats [40,41].

The B. laevigata plants occurring in the Tatra Mountains were characterized by very large variations in size and shape. Depending on the habitat conditions (xerothermic position or more damp) the average leaf length ranged from $5( \pm 2) \mathrm{cm}$ to $9( \pm 3.7) \mathrm{cm}$, and leaf width from $0.9( \pm 0.3) \mathrm{cm}$ to $1.0( \pm 0.4) \mathrm{cm}$ (respectively). The leaves of these plants had a small number of hairs on the surface of the leaf blade, the leaf surface was shiny and the leaves were dark green [28]. The period of entry into the generative phase of the B. laevigata plants was very varied and depended on the altitude, in which the plants grew. In the upper parts of the mountains the plants flourished and fruited in August and September, while in the valleys in June and July. The $B$. laevigata plants growing in the Tatra Mountains produced relatively large seeds (on average $3 \mathrm{mg} \pm 0.2 \mathrm{mg}$ ) which germinated in $85 \%$. The ability to germinate has been maintained for 3 years [28].

The research shown that very high morphological diversity of the $B$. laevigata plants in the Tatra Mountains is due to habitat differences such as temperature (height of $\mathrm{m}$ a.s.l.), sunlight (exposure of a mountain slope) and water availability. All plants bred from seeds of the Tatra

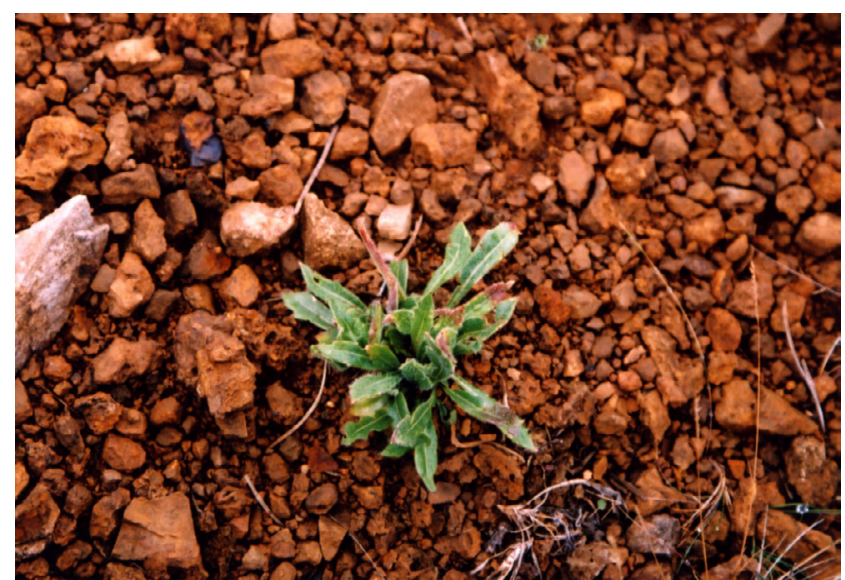

Figure 2: B. laevigata on calamine substrate (xerothermic post) - calamine waste heap in Boleslaw near Olkusz [4].

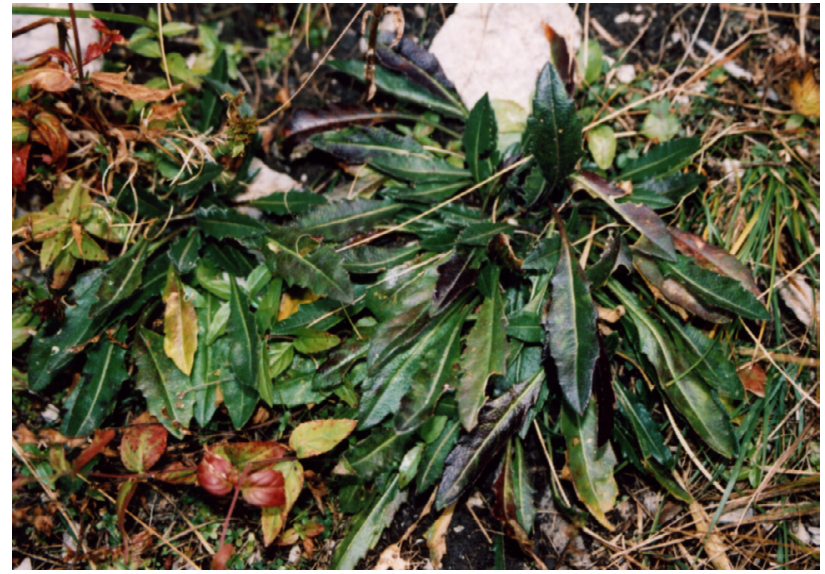

Figure 3: B. laevigata on humid post near the stream - Jaworzynka Valley (western Tatra Mountains) [4]

Mountains plants that differed morphologically, after being grown in a greenhouse (under equal conditions) were of equal size and with the same morphological characteristics [37]. The genetic studies of these plant populations (the AFLP method) have also shown their similarity at the DNA level. The analyzes have shown that the Tatra populations do not differ significantly genetically due to the presence of significant flow of genes between them [17].

The B. laevigata plants occurring in the Tatra Mountains contained increased amounts of heavy metals in their tissues - which was found for the first time by Godzik [41-43]. This result was surprising. It was found that the increase of the amount of metals in the B. laevigata tissues was a consequence of the growth of these plants on the metalbearing substrate present in some regions of the Tatra Mountains. There are some historical records about iron industry in the Tatra Mountains in the $19^{\text {th }}$ century. However, the content of heavy metals in the $B$. laevigata plant tissues was lower than in the plants from the waste heap population from Boleslaw $[4,28,39]$.

Biscutella laevigata plants from the waste heap in Boleslaw and from the Tatra Mountains during growth under equal conditions

Under the natural conditions, there are significant morphological differences between the B. laevigata plants coming from Boleslaw calamine waste heaps and from the Tatra Mountains. This can be caused both by the environmental conditions and genetic differences between those two groups of plants [10]. The issue was resolved with observations of growth and development of the B. laevigata plants cultivated in the identical, greenhouse conditions. Seeds for this experiment originated from the calamine waste heap of Boleslaw (the waste heap population), and from the Jaworzynka valley of the Tatra Mountains (the Tatra population). Two next generations of plants were investigated [28].

The plants of two studied populations cultivated in a greenhouse did not differ in size (Figure 4). All the plants were of similar size, also bloomed and fruited at the same period of time (June). However, those two populations differed in some other morphological features, which persisted in next generations of plants [28]. the color (Figure 4), thickness of a leaf blade, coverage of leaves with trichomes (Figures 5 and 6) and size of seeds were different in two studied populations. The leaves of the waste heap plants were light green with a thin leaf blade and were rich in trichomes. The seeds of the waste heap population 
Citation: Wierzbicka M, PielichowskaM, Bemowska-Kałabun O, Wąsowicz P (2017) Microevolution on Anthropogenically Changed Areas on the Example of Biscutella laevigata Plants from Calamine Waste Heap in Poland. J Environ Anal Toxicol 7: 471. doi: 10.4172/2161-0525.1000479

Page 4 of 10

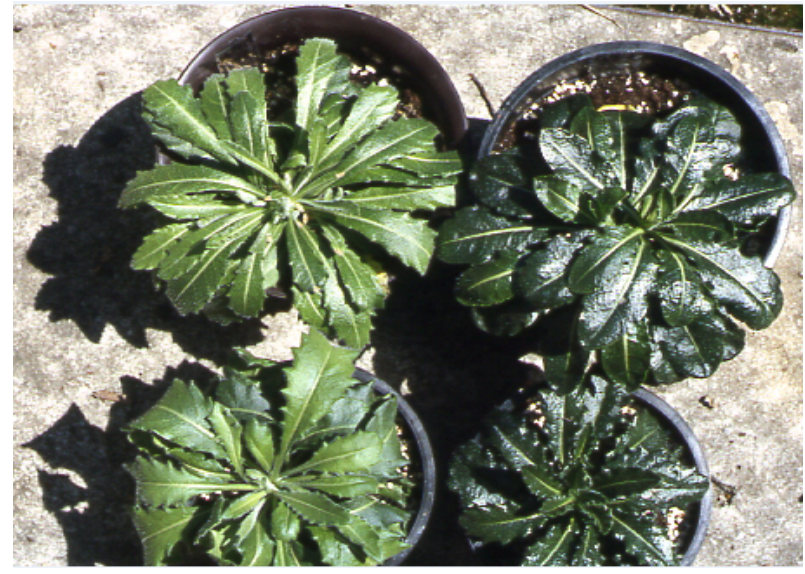

Figure 4: B. laevigata plants from waste heap and Tatra Mountains populations, cultivated in gardening soil under greenhouse conditions. Plants cultivation time was 5 months. Waste heap population (in left) has light green leaves. Plants from Tatra Mountains population (in right) have dark green leaves and shiny leaves $[4,28]$

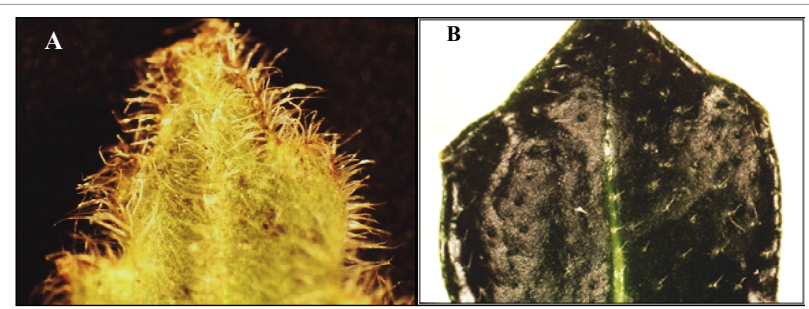

Figure 5: Leaf of $B$. laevigata plant from the populations: (a) waste heap in Boleslaw near Olkusz (leaf blade is light green and covered with numerous trichomes), (b) Tatra Mountains (leaf blade is dark green and covered with few trichomes; shiny leaf surface indicates the presence of wax layer). Leaf view from stereoscopic microscope (magnification 4X) [4].

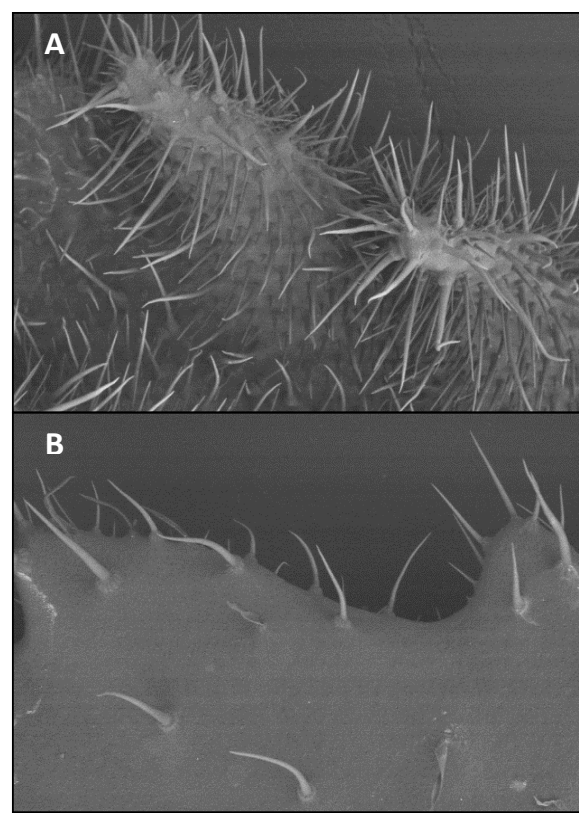

Figure 6: (a) Numerous of epidermal trichomes on leaf surface of $B$. laevigata plant from waste heap population. (b) Few epidermal trichomes on leaf surface of $B$. laevigata plant from Tatra Mountains population. Plants were grown in a greenhouse, in gardening soil, for a period of 5 months. Images from scanning electron microscope, magnification 400X [4]. were small (on average $18 \pm 1 \mathrm{mg}$ ). In contrast, the leaves of plants originated from the Tatra Mountains were dark green with a thicker leaf blade and poorly covered with trichomes. The difference between thickness of leaf blades of both populations of plants was a reason of the observed difference in theleaves color (which was confirmed by measurements of the chlorophyll content). The enhanced thickness of a leaf blade within mountain population was caused by an increase of size of the palisade mesophyll cells, which is related to increased capacity of water accumulation [28]. Seeds from the mountain population were big (on average $30 \pm 1 \mathrm{mg}$ ).

Both populations of $B$. laevigata differed significantly in their tolerance level to lead, zinc and cadmium. The seedlings of the $B$. laevigata plants were examined in a short-term test (7-10 days). The elevated level of tolerance (20-100\%) to all three studied metals $(\mathrm{Pb}, \mathrm{Zn}$, $\mathrm{Cd}$ ) in two next generations of the waste heap population was found on the basis of the root growth ratio (the Wilkins test) in comparison to the mountain population [28]. The adult individuals of $B$. laevigata were also investigated in the long-term test (about 30 days) where growth of plants was compared. These studies also showed an increased tolerance to lead, cadmium and zinc of the $B$. laevigata waste heap population (about 20-100\%) compared to the Tatra Mountains population [37].

The comparative research on morphology and tolerance to heavy metals, carried out under equal habitat conditions, showed a significant difference between two studied populations of the B. laevigata plants (the waste heap and Tatra Mountains populations). These features were genetically fixed, because they occurred in the next two generations of this plants $[28,37]$.

\section{Biscutella laevigata - Facultative Metallophyte}

Plant species occurring on metallic soils are called metallophytes. They may be either obligatory metallophytes - if they occur only on metallic soils or optional metallophytes - if they occur on both metallic and normal soils [4].

To which of these groups does B. laevigata belong? This determines the occurrence of this species in Europe. In Poland, both in the Tatra Mountains and on the zinc-lead heaps in Boleslaw near Olkusz, the amounts of metals in the soil are elevated (although on the heap in Bolesław metal concentrations are two or three orders of magnitude higher than in the Tatra Mountains soils). B. laevigata was also found in France on the zinc-lead heap in Les Malines (Las Aviniēres) near Montpellier which was a habitat similar to the Polish waste heap near Olkusz. On this heap the following metal concentrations were found: $\mathrm{Zn}-15000 \mathrm{mg} / \mathrm{kg}, \mathrm{Pb}-5000 \mathrm{mg} / \mathrm{kg}, \mathrm{Tl}-40 \mathrm{mg} / \mathrm{kg}$ [44]. In the Austrian Alps, the presence of $B$. laevigata was found on the metal-bearing site near the Gailitz river [38], where the metal concentrations in the soil were very high: $\mathrm{Zn}$ - to $75000 \mathrm{mg} / \mathrm{kg}, \mathrm{Pb}$ - to $4000 \mathrm{mg} / \mathrm{kg}$, Cd - to $44 \mathrm{mg} / \mathrm{kg}$. However, B. laevigata has also been found in areas with not increased amounts of heavy metals. These are the Austrian Alps in the Hochobir region, where the metal concentrations are: $\mathrm{Zn}-63 \mathrm{mg} / \mathrm{kg}$; $\mathrm{Pb}-33 \mathrm{mg} / \mathrm{kg}$; $\mathrm{Cd}-0.03 \mathrm{mg} / \mathrm{kg}$ [38].

Considering that the Polish habitats of $B$. laevigata are characterized by elevated heavy metals in the subsoil, and that $B$. laevigata has been found on metal-rich soils in France and Austria, this species can be considered as a metallophyte. Because the B. laevigata occurrence sites are also described on soils with no elevated concentrations of heavy metals, it can be stated that B. laevigata belongs to optional metallophytes.

The B. laevigata preference for growth on metal-bearing soils is, 
Citation: Wierzbicka M, PielichowskaM, Bemowska-Kałabun O, Wąsowicz P (2017) Microevolution on Anthropogenically Changed Areas on the Example of Biscutella laevigata Plants from Calamine Waste Heap in Poland. J Environ Anal Toxicol 7: 471. doi: 10.4172/2161-0525.1000479

however, very high. We found it by examining whether B. laevigata from the Tatra Mountains population (with lower tolerance for heavy metals) would be able to grow on a zinc-lead subsoil from calamine waste heap. It turned out that both the Tatra Mountains and waste heap populations were growing well on the waste heap substrate. All tested plants developed and bloomed at the same rate. After 5 months the plants cultivated on the calamine subsoil (from both waste heap and Tatra Mountains populations) contained in their tissues: about $700 \mathrm{mg} \mathrm{Pb} / \mathrm{kg}$ dry mass, $8000 \mathrm{mg} \mathrm{Zn/kg} \mathrm{dry} \mathrm{mass,} 75 \mathrm{mg} \mathrm{Cd} / \mathrm{kg}$ dry mass and $70 \mathrm{mg} \mathrm{Tl} / \mathrm{kg}$ dry mass. This demonstrates the great ability of this species to accumulate heavy metals in tissues, in the absence of symptoms of their toxic effects, thus a high tolerance to heavy metals [4]. It should be accepted that B. laevigata belongs to optional metallophytes, demonstrating at the same time a high preference for growth on metallic soils.

\section{Biscutella laevigata - Hyperaccumulator of Heavy Metals}

Hyperaccumulators are the plant species, which grow in soils enriched in metals and are able to accumulate in their shoots very high amounts of metals: $\mathrm{Cd}>100 \mathrm{mg} / \mathrm{kg} ; \mathrm{Pb}>1000 \mathrm{mg} / \mathrm{kg} ; \mathrm{Zn}>10000 \mathrm{mg} / \mathrm{kg}$. For thallium the limit value was set at $>500 \mathrm{mg} / \mathrm{kg}$ dry mass $[44,45]$ or $>100 \mathrm{mg} / \mathrm{kg}$ dry mass [46]. The hyperaccumulator plants are constantly sought because of their ability to be used for purification of soils from heavy metals (phytoremediation) $[47,48]$.

B. laevigata is classified as a hyperaccumulator of such metals as thallium and lead $[38,44,49]$. In the research on several plant species from the zinc-lead heaps (enriched in nickel, thallium and gold) occurring near Montpellier (France), the thallium deposition in the B. laevigata plants was observed - above $1.5 \%$ [44]. On this basis $B$. laevigata was included to hyperaccumulators of thallium. In other studies Wenzel and Jockwer [38] found the lead content of more than $1000 \mathrm{mg} / \mathrm{kg}$ dry mass in the shoots of B. laevigata. On this basis $B$. laevigata was included to hyperaccumulators of lead.

The $B$. laevigata heap population, which grows on the calamine waste heap in Boleslaw near Olkusz, shows a high potential for hyperaccumulation of lead, zinc and cadmium. This is accompanied by the changed mineral economy of these plants. Both the heap and Tatra populations of B. laevigata are characterized by the ability to hyperaccumulate thallium. In this case, it is a species characteristic [17$18,28]$

\section{Adaptation of Biscutella laevigata Plants to Growth on Calamine Waste Heap in Boleslaw near Olkusz}

Plants that colonize harsh habitats, for example acidic, metallic or serpentine soils, must have morphological and physiological plasticity [50,51]. Some of the features, that allow growth of the B. laevigata plants on metalliferous heaps, must be particularly well developed and genetically fixed, to allow the development of these plants under extremely unfavorable conditions, such as: excessive amount of heavy metals, water deficit, strong insolation, or insufficient amount of humus in the substrate [4].

\section{Alkaline soil $\mathbf{p H}$}

One of the qualities, that connect the B. laevigata waste heap and Tatra Mountains populations from Poland, is a large amount of calcium in the substrate and therefore alkaline $\mathrm{pH}$. On the heap in Boleslaw the amount of calcium is very high $-73873 \mathrm{mg} / \mathrm{kg}$ dry mass, at pH $7.81( \pm$ $0.06)$. In the Tatra Mountains, the amount of calcium is even higher and is $250000 \mathrm{mg} / \mathrm{kg}$ dry mass, at $\mathrm{pH} 7.3$ [42] or $118000 \mathrm{mg} / \mathrm{kg}$ dry mass [36]. As a reference, the geochemical background for calcium in soils of Poland is $1700 \mathrm{mg} / \mathrm{kg}$ dry mass, at pH 5.9 [52]. The large amount of calcium in subsoil seems to be important to this species, because the occurrence of B. laevigata in the Tatra Mountains is connected only with their western part, where there are limestone rocks. It is known that large amounts of calcium and alkaline soil $\mathrm{pH}$ favor low toxicity of heavy metals for plants. Under these conditions, there are smaller amounts of metals in the soluble forms that are available to the plants. Thus, a significant feature of soils, which is preferred by the B. laevigata plants in metallic areas, is the high content of calcium. If it is accompanied by high concentrations of metals, then under these conditions they are less toxic for plants [4].

\section{The clonal form of vegetative propagation}

The $B$. laevigata plants exhibit high tolerance to heavy metals, but its level depends on the plant development phase. When 2-weekold seedlings were planted to the calamine substrate, growth and development of these plants was strongly inhibited, and after 2.5 months the seedlings were dying. On the other hand, when plants were over 2 months old, their growth was carried out without disturbance, and even those plants were larger than the control group (from 105\% to $160 \%$ of control). Greater sensitivity of seedlings for growth in calamine substrate was associated with the accumulation by these plants several times more metals than older plants. For example, the concentration of lead in seedlings was on average $2000 \mathrm{mg} / \mathrm{kg}$ dry mass, while in mature plants an average of $300 \mathrm{mg} / \mathrm{kg}$ [37]. If the B. laevigata plants at theseedling stage are so sensitive to growth in the calamine substrate, the question arises how the adult plants can develop and occur so frequently on the waste heap? The answer is the ability of this species to form a clonal form of vegetative reproduction. Young plants are formed from root buds and are so abundant, that in one growing season of cultivation one plant was capable of producing up to 15 progeny plants via vegetative propagation [37].

The vegetative reproduction is an energy-consuming process for plants [53], which results from the high expenditure for production of propagules. However, this kind of reproduction provides reproductive success in difficult habitat conditions, which include zinc-lead waste heaps, scree and mountain slopes. Thus, the vegetative propagation plays a very important role in the survival strategy of the $B$. laevigata species in difficult conditions of growth. The growth of seedlings on the calamine substrate is weak and enables only survival of individuals with the best adaptability, through strict selection [4]. The described example is a regularity among clonal plants, which allows to maintain a balance between new genotypes introduced into the environment as a result of sexual reproduction and replication by vegetative reproduction of individuals (clones) best suited to locally prevailing habitat conditions [53]. Thus, the growth of $B$. laevigata under conditions which are too unfavorable for other species is possible thanks to the clonal vegetative propagation. As a result of generative propagation, a considerable amount of seeds are produced and several years of their duration assure the diversity of the B. laevigata genetic pool. This is a pioneer species strategy [4].

\section{Removal of heavy metals by the oldest and drying leaves}

The uptake of metals from metalliferous ground by the B. laevigata plants is a process that grows over time. This is demonstrated by a double increase in the amount of zinc in plants in autumn, compared to the beginning of the growing season, and also the fact that the maximum concentrations of the elements were found in the oldest 
Citation: Wierzbicka M, PielichowskaM, Bemowska-Kałabun O, Wąsowicz P (2017) Microevolution on Anthropogenically Changed Areas on the Example of Biscutella laevigata Plants from Calamine Waste Heap in Poland. J Environ Anal Toxicol 7: 471. doi: 10.4172/2161-0525.1000479

Page 6 of 10

tissues [37]. Similar dependencies for the B. laevigata plants have also been described by Godzik [41,42], and for other plant species Ernst [54]. B. laevigata is a perennial plant, so in the field research both annual plants could be considered as well as growing in this area for many years. For this reason, the research on plants of the same age was also carried out. To the calamine ground adult plants of $B$. laevigata were transplanted for a period of 5 months. After this time, in the oldest and withering leaves a very high amount of heavy metals - lead $277 \mathrm{mg} /$ $\mathrm{kg}$ dry mass, zinc $2787 \mathrm{mg} / \mathrm{kg}$ dry mass was found, whereas in mature green leaves respectively - lead $150 \mathrm{mg} / \mathrm{kg}$ dry mass and zinc $1520 \mathrm{mg} /$ $\mathrm{kg}$ dry mass was found $[17,37]$. This is proof that $B$. laevigata plants remove the excess of heavy metals by their accumulation in the oldest leaves, which then dry.

\section{Biscutella laevigata - zinc tolerant species thanks to $\mathrm{Zn}$ - chelate with nicotinamine}

It is still important to consider whether the tolerance to heavy metals in the $B$. laevigata plants is particularly high or average compared to other plant species? For this purpose, a comparative study of the tolerance level to heavy metals (zinc, lead, cadmium) of the two populations of $B$. laevigata (the waste heap and Tatra plants) with other plant species was conducted, I. a. Cucumis sativus, Phaseolus vulgaris, Zea mays [3,4]. It has been shown that the tolerance of B. laevigata to zinc is exceptionally high. During the 10-day test, zinc caused inhibition of root growth of the examined plant species (20-60\% control), except for B. laevigata, in which zinc stimulated root growth - in the natural population up to $130 \%$ control, and in the heap populations - up to $200 \%$ in comparison to the control group. The roots of the $B$. laevigata plants contained very large amounts of zinc - the heap population $20000 \mathrm{mg} / \mathrm{kg}$ dry mass, on average, and the Tatra population 10000 $\mathrm{mg} / \mathrm{kg}$ dry mass, while the other plant species were from $4000 \mathrm{mg} / \mathrm{kg}$ dry mass up to $9000 \mathrm{mg} / \mathrm{kg}$ dry mass. Similar results were obtained in long-term tests when different plant species were cultivated at different zinc doses for 2 months $[3,4]$. It has been shown that $B$. laevigata plants (especially the heap populations) have been shown to grow better and develop in the presence of zinc, in a dose that inhibits growth and development in other plant species. Therefore, B. laevigata is not only tolerant to zinc, but its high concentration also favors its growth and development $[4,55]$.

The question remains, what processes are at the base of the $B$. laevigata growth stimulation by zinc? To answer this question, the chemical forms of zinc in B. laevigata were investigated through the speciation analysis. The study was done by modern methods of analytical chemistry - using a complex chromatographic system SE/HILIC-ICP-MS multidimensional chromatography. Based on the obtained spectra, it was found that zinc is present in the B. laevigata plants as the nicotinamine complex. However, no complexes of metals with phytochelatins were found, which was contrary to the expectations $[4,37]$.

According to the literature, the nicotinamine is known to play an important role in plant tolerance to heavy metals. It has an ability of metal chelation, it can mediate in loading and unloading of phloem [56]. Among the species hyperaccumulating zinc, e.g., Arabidopsis halleri [57], genes encoding the nicotinamine synthase were found. At the cellular level, complex compounds of the nicotinamine with metals are removed from the cytoplasm into the vacuole where they are isolated and detoxified. The nicotinamine plays an important role in the transport of such elements as zinc, copper, iron, nickel or manganese $[58,59]$. The presence of nicotinamines bonded with zinc as complex compounds as a response to elevated zinc concentration in the $B$. laevigata plants is undoubtedly related to the phenomenon of extremely high zinc tolerance of this species.

\section{Trichomes on the leaves accumulate metals, increasing the tolerance of plants to metals}

The way of uptake and translocation of metals in the B. laevigata plants was investigated by histochemical ditizone method (Figure 7) $[4,60]$. Metals (lead, cadmium and zinc) were taken up by root hairs (Figure $7 \mathrm{~b}$ ), then passed through the primary bark tissue and, after overcoming the endoderm barrier, penetrated the root canal (Figure 7c). Then, through vascular bundles, they were transferred from the roots to the aboveground parts and to the leaves. In leaves, the largest amounts of metals were present in the vascular bundles (Figure $7 \mathrm{~d}$ ), where the metals were transported to the leaf surface tissues - epidermis cells and epidermal trichomes on the leaves (Figure 7e and 7f) [4].

An analysis of the trichomes from the epidermis of $B$. laevigata grown on the calamine soil was conducted using LA-ICP-MS. After the laser beam was routed in parallel to the leaf edge in the zone of the occurrence of epidermal trichomes, the presence of the following elements was noted: the largest quantities were reported for calcium and manganese, in minor magnesium, thallium, and lead (Figure 8), and in the smallest - zinc and cadmium. All heavy metals present in excessive amounts in the calamine waste heap: zinc, lead, cadmium and thallium were detected in trichomes $[4,18]$.

Ttichomes of B. laevigata are alive and unicellular (Figure 7f). At the base of a trichome there is a central, large vacuole. The histological studies using the ditizone method have shown that the largest amounts of metals were deposited in this part of the trichome [60]. Hence, trichome cells (especially vacuoles) are areas where excessive amounts of harmful elements are stored. This allows to protect other leaf cells [61]. The presence of numerous trichomes on leaves enables the detoxification of significant amounts of metals in B. laevigata plants growing on metalbearing areas. It should be noted that the calamine heap population of

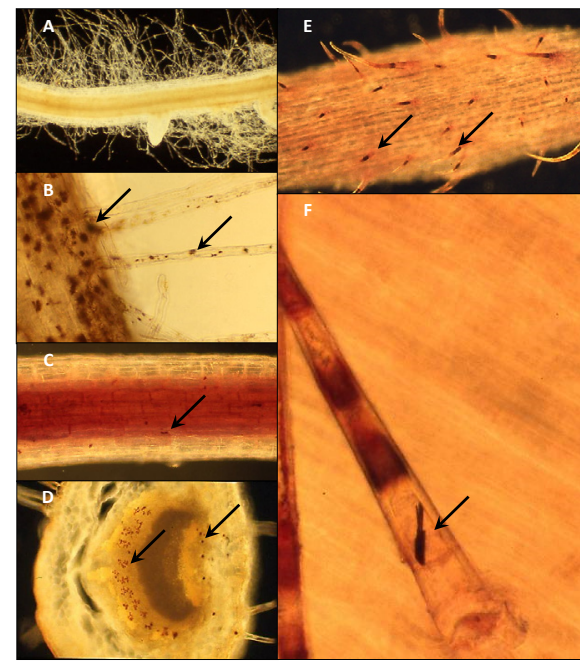

Figure 7: B. laevigata plants, visualization of heavy metals in tissues by dithizone method. (a) Fragment of the root - control; no coloring after histochemical reaction; light microscope - dark field, magnification 30x. (b) In rhizoderma cells of root and in rootstocks cadmium in the form of numerous deposits (arrows); light microscope, magnification 220X. (c) Small lead deposits and red dots in the stele of the root marking the presence of lead (arrows); light microscope - dark field, magnification 60X. (d) Vascular bundle of the leaf, cadmium deposits in the xylem (arrows); light microscope - dark field, magnification 60X. (e) leaf epiderme with epidermal trichomes, in which heavy metals are present (arrows); Light microscope - dark field, magnification 25X. (f) Heavy metal deposits in leaf epidermis (arrows); light microscope, magnification $50 X[4,18]$. 
Citation: Wierzbicka M, PielichowskaM, Bemowska-Kałabun O, Wąsowicz P (2017) Microevolution on Anthropogenically Changed Areas on the Example of Biscutella laevigata Plants from Calamine Waste Heap in Poland. J Environ Anal Toxicol 7: 471. doi: 10.4172/2161-0525.1000479

Page 7 of 10

B. laevigata is distinguished by the large number of trichomes on the leaves (Figures $5 \mathrm{a}$ and $6 \mathrm{a}$ ), compared to the Tatra population (Figures $5 \mathrm{~b}$ and $6 \mathrm{~b})$. This feature of the heap population favors the detoxification of excessive amounts of metals in the aboveground parts of the plant, thus being a beneficial feature for the growth of these plants on zinclead heaps.

\section{Detoxification of metals - accumulation in cell walls, intercell spaces and vacuoles}

Of all the organs, the roots of the B. laevigata plants absorbed and

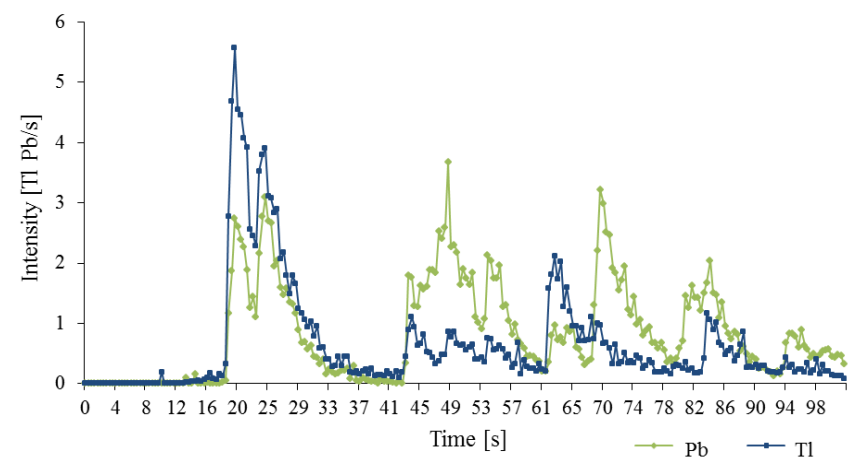

Figure 8: Elemental analysis of leaf epidermal trichomes - performed with LA ICP MS. Profile for $\mathrm{TI}$ and $\mathrm{Pb}$ in the trichomes of plant from waste heap $(\mathrm{F} 1 \mathrm{H})$ cultivated in calamine with $3 \mathrm{mM} / \mathrm{kg}$ EDTA $[4,18]$

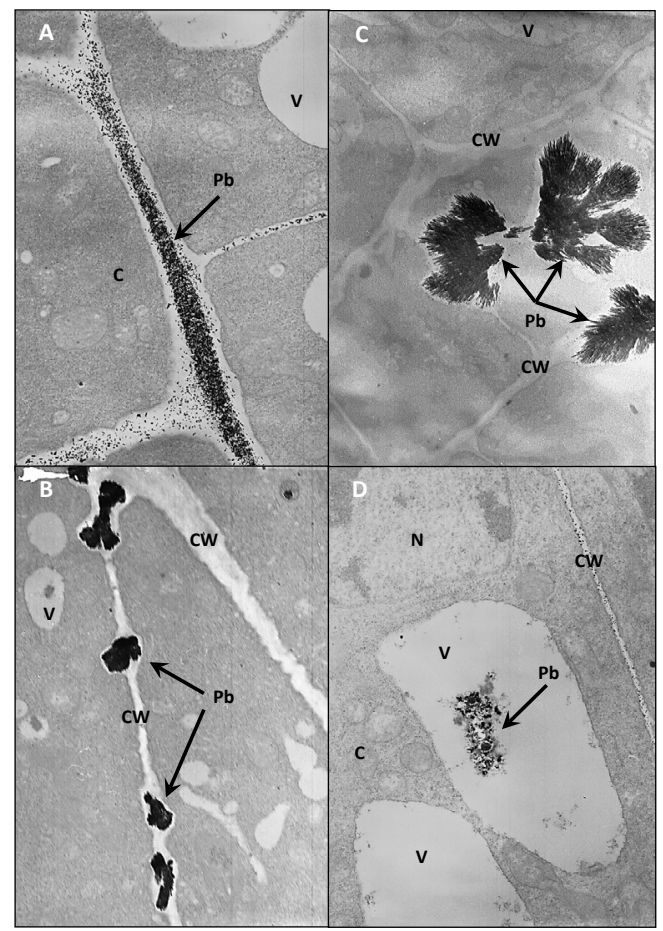

Figure 9: (a) Lead (big black deposits) in cell walls of root tip. Cell walls are thickened in areas of lead accumulation; transmission electron microscopy; magnification 10000X (b) lead (big black deposits) in cell walls of root tip transmission electron microscopy; magnification 8000X. (c) Lead (numerous black deposits) in cell walls and intracellular spaces of root tip; transmission electron microscopy; magnification 8000X (d) lead (black deposits) in cell walls and vacuoles of cells of primary mesophyll in root tip; transmission electron microscopy, magnification 3400X. Captions: $\mathrm{V}$ - vacuole, CW - cell wall, C cytoplasm, $\mathrm{N}$ - nucleus, $\mathrm{Pb}$ - lead [4]. accumulated the largest amounts of metals in their tissues. When adult plants were given lead, zinc or cadmium salts in liquid medium for 12 days, $99 \%$ lead, $75 \%$ zinc and $68 \%$ cadmium were stored in the roots. The remaining amount of metals was transported to the aboveground parts. The amount of metals in the roots repeatedly exceeded the concentration of their soluble forms in the surrounding environment. For example, the lead in liquid medium was $2.5 \mathrm{mg} / \mathrm{dm}^{3}$, whereas after 12 days of incubation of the B. laevigata plants in the lead medium, the metal was present (depending on the development phase of the plant and its organ) in the concentration of $20-10000 \mathrm{mg} / \mathrm{kg}$ dry mass [37].

So, the question arises where exactly the metals are stored within root cells, since despite such a huge amount of metals accumulated, the $B$. laevigata plants have maintained the potential for growth and development. The transmission electron microscopy techniques have resulted in visualization of lead in root tip cells. It was found that lead was accumulated mostly in cell walls (Figure 9a), which was often accompanied by an increase in their thickness (Figure 9b). Lead was also present in intercellular spaces (Figure 9c), significant amounts were also found in cellular vacuoles (Figure 9d) [4,37].

Thus, detoxification of metals in $B$. laevigata involves the accumulation of metals in vacuoles, cell walls and intercellular spaces. Even toxic compounds, if retained in these cell areas, are not involved in cell metabolism and remain nontoxic to plants $[4,37]$.

\section{Taxonomic Rank of Waste Heap Population - Biscutella laevigata Subsp. woycickii}

The previous studies have shown that two populations of the $B$ laevigata plants occurring in Poland, at locations $120 \mathrm{~km}$ apart, strongly differ from one another with many genetically fixed morphological features $[17-18,28,37,60]$.

The first important issue is characteristics related to adaptation to water deficits, that is the thickness of the leaf blade and the intensity of leaf cover with epidermal trichomes. These adaptations developed independently in each of those populations in two different directions. The leafs of the heap population are thinner, but covered with more trichomes, protecting the plants against excessive water loss (transpiration). These trichomes are actually alive, but their outer cell wall is thick enough to limit the transpiration. However, the leaves in the Tatra population have few trichomes but their leaf blade is thicker due to the increased size (vacuolization) of leaf mesophyll cells [28]. This enables increased water storage in the leaves and secures the plant from its deficit $[10,62]$.

The second group of features that differentiate the waste heap population from the Tatra one are the features associated with adaptation of plants to excessive heavy metals content in the soil. The heap populations show much higher levels of tolerance to heavy metals (lead, zinc, cadmium) than plants of the Tatra population. The zinc tolerance of the waste heap plants is so high that they can be counted as zinc metalophytes. The Tatra population is much less tolerant to zinc [4]. The most significant difference between these two populations is the high potential for the accumulation of heavy metals (lead, zinc and cadmium) in the heap population, which is accompanied by changed mineral economy of these plants. Such properties were not found in the plants of the Tatra population [17].

In view of such significant differences between the $B$. laevigata populations expressed on the morphological, anatomical and physiological levels, genetic studies have also been carried out, which enabled to discover the genetic structure of both populations of this 
Citation: Wierzbicka M, PielichowskaM, Bemowska-Kałabun O, Wąsowicz P (2017) Microevolution on Anthropogenically Changed Areas on the Example of Biscutella laevigata Plants from Calamine Waste Heap in Poland. J Environ Anal Toxicol 7: 471. doi: 10.4172/2161-0525.1000479

Page 8 of 10

species. The study was designed to determine how the calamine waste heap area was colonised by the B. laevigata plants and whether it happened relatively recently (about 100 years ago) or much earlier [17].

Taking into account the distance of the population from the calamine areas to the Tatra populations (about $120 \mathrm{~km}$ in a straight line) and the fact that the first mention of the B. laevigata population developing in the metallurgical areas near Olkusz dates back to 1876 [34], we can suspect that colonization of waste heaps by B. laevigata occurred recently (about 130 years ago), therefore this process can be described as "long-distance migration". It was expected that both of these facts (relatively recent waste heap colonization and long-distance plant migration) contributed to reduction of the genetic diversity of the heap population as compared to the Tatra populations. Assuming this initial hypothesis, it was expected that the genetic distances between the studied populations will be small and there will be no genotypes unique for the waste heap population. However, the studies have shown the opposite: the level of genetic diversity (determined using the AFLP markers) was comparable in all analyzed populations, irrespective of their origin (calamine waste heap, Tatra Mountains). Also genetic distances that can be read as an indicator of genetic similarity or difference between populations have proven to be highly diverse. The genetic distance measured between the heap population and each of the Tatra populations was over 30 times greater than the genetic distance between the Tatra populations. The research has also shown the presence in the heap population of genotypes not found in the Tatra populations. The flow of genes between the Tatra populations and the waste heaps has probably stopped at least a few thousand years ago. This is evidenced by the strong genetic diversity of the analyzed populations (Figure 10) [17]. The existence of strong genetic diversity between the Tatra and Boleslaw populations was also demonstrated by BabstKostecka et al. [63]

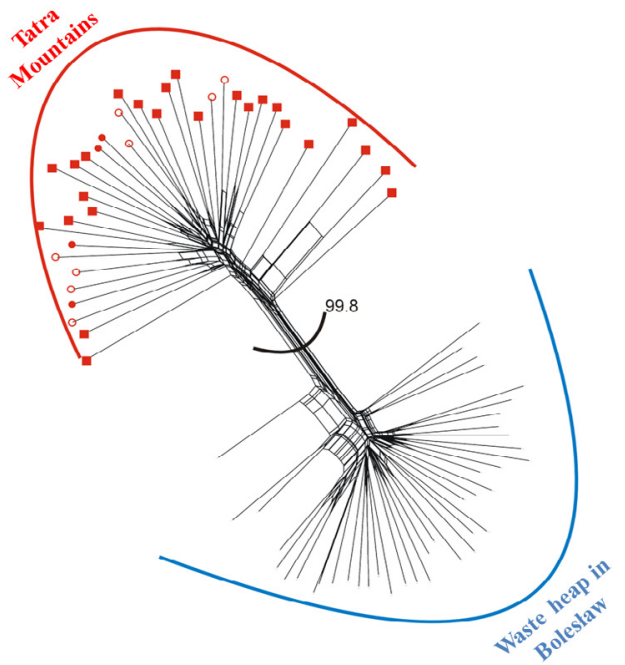

Figure 10: Neighbour Net showing genetic correlations between $B$. laevigata populations from waste heap in Boleslaw and Tatra Mountains, developed on the basis of AFLP marker variability data. Various symbols in red indicate the origin of individuals from different populations in the Tatra. It is clear that the population of calamine heap is distinctly different from the Tatra population in terms of genetics. The absence of grouping of individuals from the Tatra populations into distinct groups according to their origin may indicate that there is a significant flow of genes between them. The number above the main branch of the network is the bootstrap value coefficient used to test the "reliability" of the network topology. A factor of up to 100 indicates the high reliability of the obtained image of the genetic structure $[4,17]$.
In literature, there are examples of the formation of tolerant plant populations over a relatively short period of time in response to adverse environmental factors [64]. The emergence of such forms of plants, which have the capacity to grow and reproduce effectively in areas with increased metal content in the soil, has usually ranged from a few dozen to several decades [65-67]. It should be noted, however, that the adaptations disclosed in these populations concerned only the physiological adjustment to the increased metal concentration. They did not include morphological and anatomical features, as is the case with B. laevigata from the calamine heap in Boleslaw. It seems that adaptation at this level requires a longer period of stress and a longer period of population isolation [17].

The observed separateness of the calamine waste heap population is the result of an evolutionary process that significantly exceeds the time period set by the first mention of B. laevigata in the vicinity of Olkusz, dating back to the second half of the $19^{\text {th }}$ century [34]. It seems that the outcroppings of the calamine (which existed long before human exploitation of metal deposits) could have become the place of evolution for the ancestors of the present population of B. laevigata, which, after the start of mining of the ores, settled the suitable anthropogenic habitat. The attempts to date the divergence of the population from the Olkusz Ore Mining District show that the genetic linkage between the Tatra and Olkusz populations was likely to have occurred during the glaciation of central Poland, which took place around 120000 years ago. Although molecular dating methods, including those used by us [68], are still being discussed, we believe that the result obtained on the basis of them may be considered probable, even more that there are other intermediate evidence that support the long isolation theory [17].

The existence of various distinctities between the natural Tatra populations included in B. laevigata subsp. gracilis and the population of calamine waste heap in Boleslaw justify the hypothesis of classifying these plants into a separate taxon. The studies have shown that this taxon, for a long time, has evolved in isolation from the rest of the population of $B$. laevigata. The differences between these two populations are so large that the heap populations in Boleslaw were given the rank of subspecies B. laevigata subsp. woycickii [17].

\section{Conclusions}

The results of the study presented in this article allow to identify the unique characteristics of $B$. laevigata plants - the waste heap population of $B$. laevigata ssp. woycickii. These plants have a number of features that allow them to grow in extremely difficult terrain heavily contaminated with heavy metals. This subspecies is particularly valuable for further investigation of plant tolerance mechanisms to heavy metals. It seems that it can also have practical application to the revitalization of postindustrial sites. Taking into consideration the very limited area of the occurrence of B. laevigata ssp. woycicki near Olkusz and the rapid transformation of this area related to industrial activity, there is an urgent need for the legal protection of these valuable plants.

Therefore, there are three subspecies of Biscutella laevigata L., present in Poland in two isolated sites: in the Tatra mountains - Biscutella laevigata L. subsp. gracilis Marck.-Laur., subsp. kerneri $[69,70]$ and in the lowland metal-bearing soils of the Olkusz Ore Mining District, in Boleslaw - Biscutella laevigata L. subsp woycickii. It is a relict subspecies, probably endemic $[4,17,28]$. The development of a separate subspecies, adapted to the heavily modified habitat of zinc-lead waste heaps is a manifestation of the occurrence of micro-evolutionary processes.

\section{Acknowledgments}

We would like to thank the Professor Krystyna Grodzińska for pointing out 
Citation: Wierzbicka M, PielichowskaM, Bemowska-Kałabun O, Wąsowicz P (2017) Microevolution on Anthropogenically Changed Areas on the Example of Biscutella laevigata Plants from Calamine Waste Heap in Poland. J Environ Anal Toxicol 7: 471. doi: 10.4172/2161-0525.1000479

this interesting research object, which is Biscutella laevigata L. In addition, we would like to thank the Professor Barbara Godzik and Professor Grażyna SzarekŁukaszewska, for cooperation and interesting discussions (Department of Ecology, W. Szafer Institute of Botany, Polish Academy of Science, Cracow, Poland). We also would like to thank the Professor Krzysztof Rostański for our field trips to the post-industrial areas (Faculty of Biology and Environmental Protection, University of Silesia, Katowice, Poland).

\section{References}

1. Ernst WH (2006) Evolution of metal tolerance in higher plants. Forest Snow and Landscape Research 80: 251-274.

2. Freeland JR (2008) Molecular Ecology. PWN, Warsaw (in Polish).

3. Wierzbicka M (1999) Comparison of lead tolerance in Allium cepa with other plant species. Environmental Pollution 104: 41-52.

4. Wierzbicka M (2015) Ecotoxicology. Plants, soil, metals. Wydawnictwo Uniwersytetu Warszawskiego, Warsaw (in Polish).

5. Fodor F (2002) Physiological responses of vascular plants to heavy metals InPhysiology and biochemistry of metal toxicity and tolerance in plants pp. 149-177.

6. Wierzbicka MH, Przedpeska E, Ruzik R, Ouerdane L, Pawlak K, et al. (2007) Comparison of the toxicity and distribution of cadmium and lead in plant cells. Protoplasma 231: 99-111.

7. Przedpelska-Wasowicz EM, Wierzbicka M (2011) Gating of aquaporins by heavy metals in Allium cepa L. epidermal cells. Protoplasma 248: 663-671.

8. Baker AJ, Proctor J (1990) The influence of cadmium, copper, lead, and zinc on the distribution and evolution of metallophytes in the British Isles. Plant Systematics and Evolution 173: 91-108.

9. Lefèbvre C, Vernet $P$ (1990) Microevolutionary processes on contaminated deposits. Heavy metal tolerance in plants: Evolutionary aspects pp 285-299.

10. Wierzbicka M, Rostanski A (2002) Microevolutionary changes in ecotypes of calamine waste heap vegetation near Olkusz, Poland: a review. Acta Biologia Cracoviensia Series Botanica 44: 7-19.

11. Baumbach $\mathrm{H}$, Hellwig FH (2003) Genetic variation within and among metal-toleran and non-tolerant populations of Armeria maritima (Mill.) Willd. sl (Plumbaginaceae) in Central and Northeast Germany. Plant Biology 5: 186-193.

12. Hildebrandt U, Hoef-Emden K, Backhausen S, Bothe H, Bozek M, et al. (2006) The rare, endemic zinc violets of Central Europe originate from Viola lutea Huds. Plant Systematics and Evolution 257: 205-222.

13. Abratowska A, Wasowicz P, Bednarek PT, Telka J, Wierzbicka M (2012) Morphological and genetic distinctiveness of the metallicolous and nonmetallicolous populations of Armeria maritima s.l. (Plumbaginaceae) in Poland. Plant Biology 14: 586-595.

14. Godé C, Decombeix I, Kostecka A, Wasowicz P, Pauwels M, Courseaux A Saumitou-Laprade P (2012) Nuclear microsatellite loci for Arabidopsis halleri (Brassicaceae), a model species to study plant adaptation to heavy metals. American Journal of Botany 99: e49-e52.

15. Przedpelska-Wasowicz E, Polatajko A, Wierzbicka M (2012) The influence of cadmium stress on the content of mineral nutrients and metal-binding proteins in Arabidopsis halleri. Water, Air \& Soil Pollution 223: 5445-5458.

16. Kuta E, Jedrzejczyk-Korycinska M, Cieslak E, Rostanski A, Szczepaniak M, et al. (2014) Morphological versus genetic diversity of Viola reichenbachiana and V. riviniana (sect. Viola, Violaceae) from soils differing in heavy metal content. Plant Biology 16: 924-934.

17. Wasowicz P, Pielichowska M, Przedpelska-Wasowicz EM, Bednarek P, SzarekLukaszewska G, et al. (2014) Physiological and genetic differentiation between metallicolous and non-metallicolous diploid populations of alpine Biscutella laevigata (Brassicacae) in the Tatra Mountains and the northern Carpathian foreland. Annales Botanici Fennici 51: 227-239.

18. Wierzbicka M, Pielichowska M, Abratowska A, Wiłkomirski B, Wysocka I, et al. (2016) Thallium Hyperaccumulation in Polish Populations of Biscutella laevigata (Brassicaceae). Acta Biologica Cracoviensia Series Botanica 58: 7-19.

19. Tutin TG, Heywood VH, Burges NA, Moore DM, Valentine DH, et al. (1964) Biscutella L. In: Tutin TG, Heywood VH, Burges NA, Valentine DH, Walters SM, et al. Flora Europea. Cambridge University Press, Cambridge 1: 325-330.

20. Szafer W, Zarzycki K (1972) The Vegetation of Poland. PWN, Warsaw (in Polish).
21. Grodzinska K, Korzeniak U, Szarek-Lukaszewska G, Godzik B (2000) Colonization of zinc mine spoils in southern Poland - preliminary studies on vegetation, seed rain and seed bank. Fragmenta Floristica et Geobotanica 45: 123-145.

22. Zajac A, Zajac M (2001) Distribution Atlas of Vascular Plants in Poland. Instytut Botaniki UJ, Krakow (in Polish)

23. Olowokudejo JD, Heywood VH (1984) Cytotaxonomy and breeding system of the genusBiscutella (Cruciferae). Plant systematics and evolution 145: 291-309.

24. Wertlen AM (2006) Evolution of flower colours: choice strategies of pollinating Hymenoptera as selection factors. Doctoral dissertation. Freie Universitat, Berlin.

25. Ellenberg H, Weber HE, Dull R, Wirth V, Werner W, et al. (1991) Zeigerwerte von Pflanzen in Mitteleuropa. Scripta Geobotanica 18: 1-248.

26. Dobrzanska J (1955) Floral and Ecological Studies on Calamine Flora in the District of Boleslaw and Olkusz. Acta Societatis Botanicorum Poloniae 24: 357-415.

27. Wierzbicka M (2002) The adaptation of plants to growth on a calamine waste heap in boleslaw near Olkusz. Kosmos 51: 139-150.

28. Wierzbicka M, Pielichowska M (2004) Adaptation of Biscutella laevigata L., a metal hyperaccumulator, to growth on a zinc-lead waste heap in southern Poland: I: Differences between waste-heap and mountain populations. Chemosphere 54: 1663-1674.

29. Nowak T, Kapusta P, Jedrzejczyk-Korycinska M, Szarek-lukaszewska G Godzik B (2011) The vascular plants of the Olkusz Ore-bearing region. W. Szafer Institute of Botany, Polish Academy of Sciences, Cracow 56: 245-260.

30. Przemyski A, Piwowarczyk R (2012) Biscutella laevigata L. in the Polish uplands - new data on its distribution from Nida Basin. Botanica - Steciana 16: 21-29.

31. Godzik B (2015) Natural and historical values of the Olkusz Ore-bearing region. W. Szafer Institute of Botany, Polish Academy of Sciences, Cracow.

32. Zarzycki K, Trzcinska-Tacik H, Rózanski W, Szelag Z, Wolek J, et al. (2002) Ecological indicator values of vascular plant of Poland. W. Szafer Institute of Botany, Polish Academy of Science.

33. Skalinska M (1950) Studies in chromosome numbers of Polish Angiosperms Acta Societatis Botanicorum Poloniae 20: 45-64

34. Uechtritz R (1877) Die wichtigeren Ergebnisse der Durchforschung der schlesischen Phanerogammenflora im Jahre 1875. Jahres-Bericht der Schlesiche Gesellschaft für vaterländische Cultur 54: 155-195.

35. Wóycicki Z (1913) Vegetation in the Kingdom of Poland IV. The calamine flora of Boleslaw and Olkusz. Kasa Mianowskiego, Warsaw: 1-33 (in Polish with German summary).

36. Szarek-Lukaszewska G, Niklinska M (2002) Concentration of some chemicals elements in Biscutella laevigata L. and Plantago lanceolata L. from calamine spoils (S. Poland). Acta Biologica Cracoviensia. Series Botanica 44: 29-38.

37. Pielichowska M (2007) Tolerance to heavy metals of the mountain plant species Biscutella laevigata. PhD Thesis, Faculty of Biology, University of Warsaw (in Polish).

38. Wenzel WW, Jockwer $F$ (1999) Accumulation of heavy metals in plants grown on mineralised soils of the Austrian Alps. Environmental Pollution 104: 145-155.

39. Miechówka A (2000) Characteristics of Tatra non-forest soils formed on carbonate rocks. Zeszyty Naukowe Akademii Rolniczej im. H. Kollataja, Cracow 263: 1-83.

40. Szafer W (1927) The Polish flora: Vascular plants of Poland and neighbouring areas. Vol. III, Polska Akademia Umiejetnosci (PAU), Cracow (in Polish).

41. Godzik B (1991) Accumulation of heavy metals in Biscutella laevigata (Cruciferae) as a function of their concentration in substrate. Polish Botanical Studies 2: 241-246.

42. Godzik B (1984) Heavy metal tolerance of select vascular plants. PhD Thesis, Institute of Botany, Polish Academy of Sciences, Cracow (in Polish).

43. Godzik B (1993) Heavy metals content in plants from zinc dumps and reference areas. Polish Botanical Studies 5: 113-132.

44. Anderson CWN, Brooks RR, Chiarucci A, La Coste CJ, Leblanc M, et al. (1999) Phytominig for nickel, thallium and gold. Journal of Geochemical Exploration 67: 407-415. 
Citation: Wierzbicka M, PielichowskaM, Bemowska-Kałabun O, Wąsowicz P (2017) Microevolution on Anthropogenically Changed Areas on the Example of Biscutella laevigata Plants from Calamine Waste Heap in Poland. J Environ Anal Toxicol 7: 471. doi: 10.4172/2161-0525.1000479

45. Leblanc M, Petit D, Deram A, Robinson BH, Brooks RR (1999) The phytomining and environmental significance of hyperaccumulation of thallium by Iberis intermedia from Southern France. Economic Geology 94: 109-114.

46. Van der Ent A, Baker AJ, Reeves RD, Pollard AJ, Schat H (2013) Hyperaccumulators of metal and metalloid trace elements: facts and fiction. Plant and Soil 362: 319-334.

47. Lasat MM (2002) Phytoextraction of toxic metals: a review of biological mechanisms. J Environ Qual 31: 109-120.

48. Salt DE, Smith RD, Raskin I (1998) Phytoremediation. Annu Rev Plant Physiol Plant Mol Biol 49: 643-668.

49. Pošcic F, Marchiol L, Schat H (2013) Hyperaccumulation of thallium is population-specific and uncorrelated with caesium accumulation in the thallium hyperaccumulator, Biscutella laevigata. Plant and Soil 365: 81-91.

50. Baker AJM (1987) Metal tolerance. New Phytologist 106: 93-111.

51. Dahmani-Muller H, van Oort F, Gélie B, Balabane M (2000) Strategies of heavy metal uptake by three plant species growing near a metal smelter. Environmental Pollution 109: 231-238.

52. Lis J, Pasieczna A (1995) Geochemical atlas of Poland 1:2500000. Polish Geological Institute, Warsaw (in Polish).

53. Falinska K (1997) Ecology of plants. PWN, Warsaw (in Polish).

54. Ernst WHO (1995) Sampling of plant material for chemical analysis. The Science of the Total Environment 176: 15-24.

55. Trabka S (2008) Comparison of zinc tolerance in several plant species. MSc Thesis, Faculty of Biology, University of Warsaw (in Polish).

56. Stephan UW, Scholz G (1993) Nicotinamine: mediator of transport of iron and heavy metals in phloem? Physiologia Plantarum 88: 522-529.

57. Weber M, Harada E, Vess C, Roepenack-Lahaye E, Clemens S (2004) Comparative microarray analysis of Arabidopsis thaliana and Arabidopsis halleri roots identifies nicotianamine synthase, a ZIP transporter and other genes as potential metal hyperaccumulation factors. Plant Journal 37: 269-281.

58. Takahashi M, Terada Y, Nakai I, Nakanishi H, Yoshimura E, et al. (2003) Role of nicotianamine in the intracellular delivery of metals and plant reproductive development. The Plant Cell 15: 1263-1280.
59. Kim S, Takahashi M, Higuchi K, Tsunoda K, Nakanishi H, et al. (2005) Increased nicotianamine biosynthesis confers enhanced tolerance of high levels of metals, in particular nickiel, to plants. Plant and Cell Physiology 46: 1809-1818.

60. Pielichowska M, Wierzbicka M (2004) Uptake and localization of cadmium by Biscutella laevigata, a cadmium hyperaccumulator. Acta Biologica Cracoviensia. Series Botanica 46: 57-63.

61. Ma JF, Ueno D, Zhao FJ (2005) Subcellular localization of Cd and Zn in the leaves of a Cd-hyperaccumulating ecotype of Thlaspi caerulescens. Planta 220: 731-736.

62. Podbielkowski Z, Podbielkowska M (1992) Plant environmental adaptation. Adaptation of plants to the environment. Wydawnictwa Szkolne i Pedagogiczne, Warsaw (in Polish).

63. Babst-Kostecka AA, Parisod C, Godé C, Vollenweider P, Pauwels M (2014) Patterns of genetic divergence among populations of the pseudometallophyte Biscutella laevigata from southern Poland. Plant and Soil 383: 245-256.

64. Briggs D, Walters SM (2000) Plant variation and evolution. Cambridge University Press, Cambridge, UK, pp: 246-250.

65. Wu L, Bradshaw AD, Thurman DA (1975). The potential for evolution of heavy metal tolerance. III. The rapid evolution of copper tolerance in Agrostis stolonifera. Heredity 34: 165-187.

66. Bradshaw AD, McNeilly T (1981) Evolution and pollution. Arnold, London.

67. Al-Hiyaly SAK, McNeilly T, Bradshaw AD, Mortimer AM (1993) The effect of zinc contamination from electricity pylons. Genetic constraints on selection for zinc tolerance. Heredity 70 : 22-32.

68. Kropf M, Comes HP, Kadereit JW (2009) An AFLP clock for the absolute dating of shallow-time evolutionary history based on the intraspecific divergence of southwestern European alpine plant species. Mol Ecol 18: 697-708.

69. Mirek Z, Piekos-Mirkowa H, Zajac A, Zajac M (2002) Flowering plants and pteridophytes of Poland - a checlist. W. Szafer Institute of Botany, Polish Academy of Sciences, Cracow.

70. Hultén E, Fries M (1986) Atlas of North European vascular plants north of the Tropic of Cancer. Koeltz Scientific. 